Research Article

\title{
Protective effect of Ipomoea aquatica against reserpine induced oxidative stress in brain using mice
}

\author{
Gaurav Dwivedi ${ }^{1}$, Vivek Tomar $^{2 *}$
}

\begin{abstract}
${ }^{1}$ Truba Institute of Pharmacy Karond,Gandhi Nagar Road, Bhopal, Madhya Pradesh, India ${ }^{2}$ Institute of Professional Studies, College of Pharmacy, Shivpuri Link Road, Gwalior, Madhya Pradesh, India
\end{abstract}

Received: 15 July 2016 Accepted: 13 August 2016

\section{*Correspondence to: \\ Dr. Vivek Tomar, \\ Email: vivek.tmr81@gmail.com}

Copyright: (C) the author(s), publisher and licensee Medip Academy. This is an openaccess article distributed under the terms of the Creative Commons Attribution NonCommercial License, which permits unrestricted noncommercial use, distribution, and reproduction in any medium, provided the original work is properly cited.

\begin{abstract}
Background: The aim of the present study was to investigate the protective potential of alcoholic extract of Ipomoea aquatica extract against haloperidol induced catatonia, reserpine induced hypokinesia and reserpine induced oxidative stress.

Methods: The mice were treated with reserpine for three days every other day. It was observed that Ipomoea aquatica MA extract significantly decreased haloperidol induced catatonia at 30, 60, 90 and 120 minutes respectively. The biochemical analysis of brain showed that the treatment with reserpine significantly enhanced peroxidation of lipid and lower levels of superoxide dismutase (SOD), catalase (CAT) and glutathione reductase (GSH), which will be an index for oxidative stress process. Co-administration of extract at (200 $\mathrm{mg} / \mathrm{kg}$ and $400 \mathrm{mg} / \mathrm{kg}$ ) significantly lowered the lipid peroxidation and reversed the decrease in brain SOD, CAT and GSH levels.

Results: It was observed that the alcoholic extract of Ipomoea aquatica had a protective role against haloperidol induced catatonia, reserpine induced hypokinesia, and reserpine induced oxidative stress.
\end{abstract}

Conclusions: Ipomoea aquatica showed significant activity at the dose of (400 $\mathrm{mg} / \mathrm{kg}$ ).

Keywords: Ipomoea aquatica, Haloperidol, Lipid peroxidation, Biochemical analysis, Oxidative stress

\section{INTRODUCTION}

The brain function as deficient in mechanisms related with the oxidative defence and hence is at a greater risk of damage mediated by reactive oxygen species (ROS), which results in molecular damage and dysfunction in cell. ${ }^{1}$ Reactive oxygen species can damage effectively any biological molecule in its vicinity including; DNA, essential proteins, and membrane lipids. ${ }^{2}$ Neurolepticinduced catalepsy has long been used as an animal model for screening drugs for parkinsonism. ${ }^{3}$ Haloperidol is an antipsychotic drug which is used in the treatment of schizophrenia and other affective disorders. Haloperidol is having the tendency to block the dopaminergic action in the nigrostraital pathway leading to a high frequency of extrapyramidal motor side effects. ${ }^{4}$ A behavioural state known as catalepsy is induced by haloperidol in animal models, in which the animals are unable to correct external imposed postures. ${ }^{5}$ The use of haloperidol has been associated with an increased level of oxidative stress in the brain. ${ }^{6}$ This evidence clearly indicates a possible role of antioxidants in the treatment of haloperidolinduced catalepsy. SOD can be used as a primary, natural, and free radical scavenging and antioxidant enzyme in the body. The estimation of the task of such antioxidant enzymes can be given in the form of SOD, catalase, or glutathione peroxidase, which can be useful to attain the therapeutic efficacy of different antioxidant agents. $^{7}$

Ipomoea aquatica is a tropical plant, semiaquatic in nature grown as a vegetable for its tender shoots and 
leaves. Its effect on $\alpha$-glucosidase inhibitory activity was studied with Ipomoea aquatica and suggested that it is a source of food that has the potential for nutraceutical enhancement and as ingredient in medicinal preparation. ${ }^{8}$ In-vitro screening for acetyl cholinesterase enzyme inhibition potential and the antioxidant activity of its extracts was studied and concluded that all four extracts has shown significant antioxidant activity in DPPH and $\mathrm{H} 2 \mathrm{O} 2$ radical scavenging assay. ${ }^{9}$ Ipomoea aquatica also shows anti-inflammatory activity mediated through inhibition of release of mediator histamine and prostaglandin and also having protein denaturation inhibition, HRBCs membrane stabilization properties. ${ }^{10}$

\section{METHODS}

\section{Collection of plant material and extraction}

Table 1: The observations for phytochemical screening of Ipomea aquatica leaves extract.

\begin{tabular}{|c|c|c|}
\hline $\begin{array}{l}\text { Active } \\
\text { constituents }\end{array}$ & Test/reagents & Observation \\
\hline \multirow{2}{*}{ Alkaloids } & Mayer's, reagents & $+\mathrm{ve}$ \\
\hline & Wagner's reagents & +ve \\
\hline \multirow{3}{*}{ Carbohydrates } & Molish's, reagent & $+\mathrm{ve}$ \\
\hline & Fehling's reagent & +ve \\
\hline & Benedict's reagent & $+\mathrm{ve}$ \\
\hline \multirow{3}{*}{$\begin{array}{l}\text { Proteins and } \\
\text { amino acids }\end{array}$} & Millon's, reagent & $+\mathrm{ve}$ \\
\hline & Biuret test & $+\mathrm{ve}$ \\
\hline & Xanthoprotein test & +ve \\
\hline Steroids & Salkowski test & -ve \\
\hline \multirow{3}{*}{$\begin{array}{l}\text { Phenolic } \\
\text { compounds } \\
\text { and tannins }\end{array}$} & Lead acetate solution & +ve \\
\hline & $5 \% \mathrm{FeCl}_{3}$ solution & +ve \\
\hline & Acetic acid solution & $+\mathrm{ve}$ \\
\hline \multirow{2}{*}{ Flavonoids } & Sodium acetate & $+\mathrm{ve}$ \\
\hline & Ferric chloride & $+\mathrm{ve}$ \\
\hline $\begin{array}{l}\text { Gums and } \\
\text { mucilage }\end{array}$ & Molishs reagent & +ve \\
\hline Glycosides & Liebermann's test & $+\mathrm{ve}$ \\
\hline Saponins & Hemolysis method & -ve \\
\hline
\end{tabular}

The leaves of the plant were collected from damp region near to various ponds of Bhopal. Herbarium of the plant was duly prepared and submitted to the Botany Department Safia Science PG College for authentication. The voucher specimen no. was (162/Bot/Safia/10). The powder material about $500 \mathrm{gm}$ was weighed and kept in a container in contact with pet ether for seven days, with vigorous shaking at regular intervals. Material was extracted with a mixture of methanol and acetone and the ratio was 70:30 respectively for one week, with sturdy shaking at regular intervals. Obtained filtrate was dried in water bath at $40^{\circ} \mathrm{C}$ where extract showed no further reduction in the mass. Dried extract was weighed and packed in air tight container.

\section{Phytochemical screening}

The freshly synthesized extract of leaf of Ipomoea aquatica was performed to ascertain the presence or, absence of particular phytoconstituents. ${ }^{11}$ The study was carried out by employing standard conventional protocols. The identification was performed by characteristic colour changes using standard procedures (Table 1).

Animals in this study were swiss albino mice were selected randomly from animal house of Pinnacle Biomedical Research Institute. All animal experimentation work and protocols were approved by Institutional Animal Ethics Committee (IAEC) of PBRI (Regd. No. 1283/C/09/CPCSEA).

\section{Toxicity studies}

\section{Acute toxicity studies}

The acute toxicity study was performed by employing (OECD)-423 guideline. The lethal dose (LD)-50 value of the extract was determined. According to the guidelines $1 / 10^{\text {th }}$ and $1 / 5^{\text {th }}$ of LD50 was selected for the experiment i.e. $200 \mathrm{mg} / \mathrm{kg}$ and $400 \mathrm{mg} / \mathrm{kg}$.

\section{Assessment of anti-oxidant activity \\ Procedure for haloperidol-induced catatonia}

Haloperidol (1 mg/kg i.p.) was selected for the present study. Catalepsy score was measured for 2 hours at onehour intervals after haloperidol administration. The mice were placed on a horizontal bar with its forepaws $(1 \mathrm{~cm}$ in diameter, $3 \mathrm{~cm}$ above the table) and the time taken to eliminate the paws from the bar (duration of catalepsy) was noted for each animal. ${ }^{12}$ Finally, scores at different time points $(30,60,90$ and 120 minutes after haloperidol injection) were added for the measurement of cumulative catalepsy score for comparison purposes. All observations were made between 10.00 and 16.00 hours in a noiseless room at $23-25^{\circ} \mathrm{C} .^{13}$

\section{Procedure for reserpine-induced hypokinesia}

OFT is a common method for exploratory behaviour and general activity in rodents (10). It was performed for 5 min in an arena $(100 \times 100 \times 40 \mathrm{~cm})$ painted with white colour except for $6 \mathrm{~mm}$ blue lines that divided the floor into 25 equal size $(20 \times 20 \mathrm{~cm})$ squares. ${ }^{14}$ Mice were placed randomly in to one of the four corners of the open field apparatus and the maze was elevated to a height of $50 \mathrm{~cm}$ from the floor then noted down the transfer latency (in seconds), peripheral squares covered and central square covered. Facing the centre and allow to explore the apparatus for 5 minutes. After 5 minutes the mice were returned to their home cage and open field was cleaned with $70 \% \mathrm{C}_{2} \mathrm{H}_{5} \mathrm{OH}$ and permitted to dry (Table 2). ${ }^{15}$ 
Table 2: Results for reserpine-induced hypokinesia.

\begin{tabular}{|llll|}
\hline Group & Latency period & Peripheral square covered & Central square covered \\
\hline Vehicle & $4.5 \pm 2.428$ & $119.33 \pm 33.85$ & $17.66 \pm 10.48$ \\
\hline Reserpine & $73 \pm 13.914 \mathrm{a}^{* * *}$ & $10.33 \pm 3.88 \mathrm{a} * *$ & $1.66 \pm 2.73 \mathrm{a}^{* * *}$ \\
\hline Extract dose 1+reserpine & $14.83 \pm 5.26 \mathrm{~b}^{* * *}$ & $59.66 \pm 27.42 \mathrm{a}^{* *}, \mathrm{~b} * *$ & $5.83 \pm 3.76 \mathrm{a}^{*}$ \\
\hline Extract dose 2+reserpine & $8.16 \pm 3.54 \mathrm{~b}^{* * *}$ & $36.5 \pm 17.09 \mathrm{a} * * *$ & $7 \pm 2.756 \mathrm{a}^{*}$ \\
\hline
\end{tabular}

Values are expressed in mean \pm SD followed by Bonferroni multiple comparison test. Significant variation as compared to vehicle treated group $(\mathrm{p}<0.001, \mathrm{p}<0.01, \mathrm{p}<0.05$. Significant variation as compared to Reserpine treated group $(\mathrm{p}<0.001, \mathrm{p}<0.01)$

Table 3: Results for reserpine-induced oxidative stress.

\begin{tabular}{|lllll|}
\hline Treatment group & SOD & GSH & LPO & Catalase \\
\hline Vehicle & $15.316 \pm 1.178$ & $10.096 \pm 1.033$ & $6.646 \pm 0.915$ & $11.583 \pm 1.49$ \\
\hline Reserpine $(1 \mathrm{mg} / \mathrm{kg})$ & $4.521 \pm 0.604, \mathrm{a}^{* * *}$ & $2.65 \pm 0.463, \mathrm{a}^{* * *}$ & $\begin{array}{l}29.068 \pm 2.419 \\
\mathrm{a}^{* * *}\end{array}$ & $\begin{array}{l}8.36 \pm 0.654 \\
\mathrm{a}^{* * *}\end{array}$ \\
\hline $\begin{array}{l}\text { Extract }(\text { lower dose) + reserpine } \\
(1 \mathrm{mg} / \mathrm{kg})\end{array}$ & $9.54 \pm 0.634, \mathrm{a}^{* * *}, \mathrm{~b}^{* * *}$ & $\begin{array}{l}6.52 \pm 0.181, \mathrm{a}^{* * *}, \\
\mathrm{~b}^{* * *}\end{array}$ & $\begin{array}{l}12.398 \pm 0.951 \\
\mathrm{a}^{* * *}, \mathrm{~b}^{* * *}\end{array}$ & $\begin{array}{l}8.463 \pm 0.706 \\
\mathrm{a}^{* * *}\end{array}$ \\
\hline $\begin{array}{l}\text { Extract }(\text { higher dose) + reserpine } \\
(1 \mathrm{mg} / \mathrm{kg})\end{array}$ & $\begin{array}{l}11.583 \pm 0.508, \mathrm{a}^{* * *}, \mathrm{~b}^{* * *}, \\
\mathrm{c}^{* *}\end{array}$ & $\begin{array}{l}7.931 \pm 0.427, \mathrm{a}^{* * *}, \\
\mathrm{~b}^{* * *}, \mathrm{c}^{* *}\end{array}$ & $\begin{array}{l}10.258 \pm 0.648 \\
\mathrm{a}^{* *}, \mathrm{~b}^{* * *}\end{array}$ & $\begin{array}{l}10.286 \pm 0.857 \\
\mathrm{~b}^{*}, \mathrm{c}^{*}\end{array}$ \\
\hline
\end{tabular}

Note-Values are expressed in mean \pm SD followed by Bonferroni multiple comparison test. Significant variation as compared to vehicle treated group $(\mathrm{p}<0.001, \mathrm{p}<0.01)$. Significant variation as compared to Reserpine treated group $(\mathrm{p}<0.001, \mathrm{p}<0.05)$. Significant variation as compared to extract dose treated group $(\mathrm{p}<0.01, \mathrm{p}<0.05)$.

Table 4: Results for reserpine-induced hypokinesia.

\begin{tabular}{|llll|}
\hline Group & Latency period & Peripheral square covered & Central square covered \\
\hline Vehicle & $4.5 \pm 2.428$ & $119.33 \pm 33.85$ & $17.66 \pm 10.48$ \\
\hline Reserpine & $73 \pm 13.914 \mathrm{a}^{* * *}$ & $10.33 \pm 3.88 \mathrm{a}^{* * *}$ & $1.66 \pm 2.73 \mathrm{a}^{* * *}$ \\
\hline Extract Dose 1+Reserpine & $14.83 \pm 5.26 \mathrm{~b}^{* * *}$ & $59.66 \pm 27.42 \mathrm{a}^{* *}, \mathrm{~b}^{* *}$ & $5.83 \pm 3.76 \mathrm{a}^{*}$ \\
\hline Extract Dose 2+Reserpine & $8.16 \pm 3.54 \mathrm{~b}^{* * *}$ & $36.5 \pm 17.09 \mathrm{a}^{* * *}$ & $7 \pm 2.756 \mathrm{a}^{*}$ \\
\hline
\end{tabular}

Values are expressed in mean \pm SD followed by Bonferroni multiple comparison test; $\mathrm{a}=$ Significant variation as compared to vehicle treated group $(\mathrm{p}<0.001, \mathrm{p}<0.01, \mathrm{p}<0.05) ; \mathrm{b}=$ Significant variation as compared to Reserpine treated group $(\mathrm{p}<0.001, \mathrm{p}<0.01)$.

Table 5: Results for reserpine-induced oxidative stress.

\begin{tabular}{|c|c|c|c|c|}
\hline Treatment group & SOD & GSH & LPO & Catalase \\
\hline Vehicle & $15.316 \pm 1.178$ & $10.096 \pm 1.033$ & $6.646 \pm 0.915$ & $11.583 \pm 1.49$ \\
\hline Reserpine (1 mg/kg) & $4.521 \pm 0.604 \mathrm{a}^{* * *}$ & $2.65 \pm 0.463 \mathrm{a}^{* * *}$ & $29.068 \pm 2.419 \mathrm{a}^{* * *}$ & $8.36 \pm 0.654 \mathrm{a}^{* * *}$ \\
\hline $\begin{array}{l}\text { Extract (lower dose) + } \\
\text { reserpine }(1 \mathrm{mg} / \mathrm{kg})\end{array}$ & $\begin{array}{l}9.54 \pm 0.634 \\
a * * *, b * * *\end{array}$ & $\begin{array}{l}6.52 \pm 0.181 \\
\mathrm{a} * * *, \mathrm{~b} * * *\end{array}$ & $\begin{array}{l}12.398 \pm 0.951 \\
a^{* * *}, b^{* * *}\end{array}$ & $\begin{array}{l}8.463 \pm 0.706 \\
a^{* * *}\end{array}$ \\
\hline $\begin{array}{l}\text { Extract (higher dose) + } \\
\text { reserpine }(1 \mathrm{mg} / \mathrm{kg})\end{array}$ & 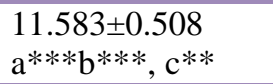 & $\begin{array}{l}7.931 \pm 0.427 \\
a^{* * *}, b^{* * *}, c^{* *}\end{array}$ & $\begin{array}{l}10.258 \pm 0.648 \\
a^{* *}, b^{* * *}\end{array}$ & $\begin{array}{l}10.286 \pm 0.857 \\
b^{*}, c^{*}\end{array}$ \\
\hline
\end{tabular}

Values are expressed in mean \pm SD followed by Bonferroni multiple comparison test; $a=$ Significant variation as compared to vehicle treated group $(p<0.001, p<0.01) ; b=$ Significant variation as compared to Reserpine treated group. $c=(p<0.001$, $p<0.05)$; Significant variation as compared to extract dose treated group $(\mathrm{p}<0.01, \mathrm{p}<0.05)$.

\section{Procedure for reserpine-induced oxidative stress}

Reserpine $(1 \mathrm{mg} / \mathrm{kg}, \mathrm{sc})$ was administered to mice for 3 days to induce oxidative stress. Vehicle treated group was given the injection of $0.5 \% \mathrm{CMC}$ in distilled water orally for 5 days and with $0.1 \%$ acetic acid solution subcutaneously (SC) for 3 days every other day. Reserpine group received $1 \mathrm{mg} / \mathrm{kg}$ of reserpine for 3 days every other day and vehicle of Ipomoea aquatica for 5 days. Ipomoea aquatica plus reserpine group was injected with $200 \mathrm{mg} / \mathrm{kg}$ and $400 \mathrm{mg} / \mathrm{kg}$ of Ipomoea aquatica per orally for 5 days and with $1 \mathrm{mg} / \mathrm{kg}$ reserpine s.c. for 3 days every other days. Behavioural assessments were carried out on 5th day after 24 hours administration of the last dose of the reserpine (Table 3). Biochemical analysis was carried out for the following studies, lipid per oxidation (LPO), and superoxide dismutase (SOD) assay.

\section{RESULTS}

The extract which was obtained from the extraction process was semisolid in nature. The final product was 
brownish black in colour with characteristic odour. The $\%$ yield of plant extract was found to be $3.83 \%$. Phytochemical analysis of the plant extract revealed the presence of carbohydrate, starch, protein, glycosides, flavonoids, alkaloids, tannic acid and phenolic compound were present in Ipomoea aquatica extract (Table 1). The measurement of acute oral toxicity was undertaken by following the OECD guidelines 423 (acute toxicity class method). There was no considerable change in the body weight was found either before or after the experimental treatment and no symptoms of toxicity were observed up to $2000 \mathrm{mg} / \mathrm{kg}$. As there was no lethality observed up to the dose of $2000 \mathrm{mg} / \mathrm{kg}$, so the $1 / 10^{\text {th }}$ and $1 / 5^{\text {th }}$ of the dose of $2000 \mathrm{mg} / \mathrm{kg}$, i.e. $200 \mathrm{mg} / \mathrm{kg}$ and $400 \mathrm{mg} / \mathrm{kg}$ was used for further investigation.

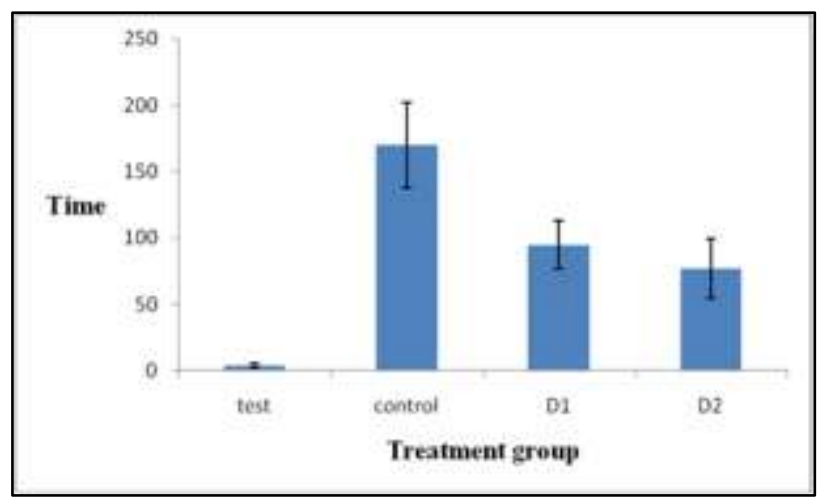

Figure 1: Haloperidol-induced catatonia after 30 minutes.

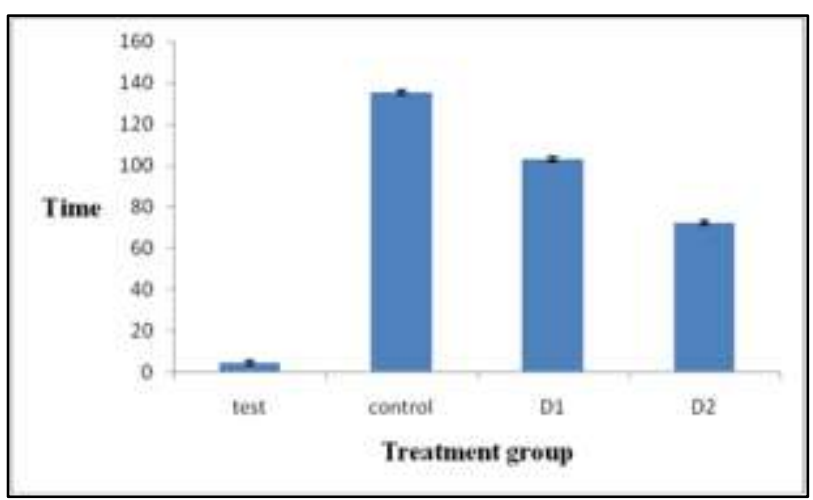

Figure 2: Haloperidol-induced catatonia after 60 minutes.

In the present investigation it was observed that Ipomoea aquatica MA extract significantly decreased haloperidol induced catatonia at 30, 60, 90 and 120 minutes respectively. Extract was found to be more effective at the dose of $400 \mathrm{mg} / \mathrm{kg}$. Thus from the result it can be postulated that selected extract possess effect on dopaminergic receptors in brain (Table 3, Figure 1, 2, 3, 4).

In the present investigation it was observed that MA extract of Ipomoea aquatica at $400 \mathrm{mg} / \mathrm{kg}$ significantly reduced reserpine induced hypokinesia. Movement in animals was found to be higher as compared to vehicle treated group (Table 4, Figure 5, 6, 7).

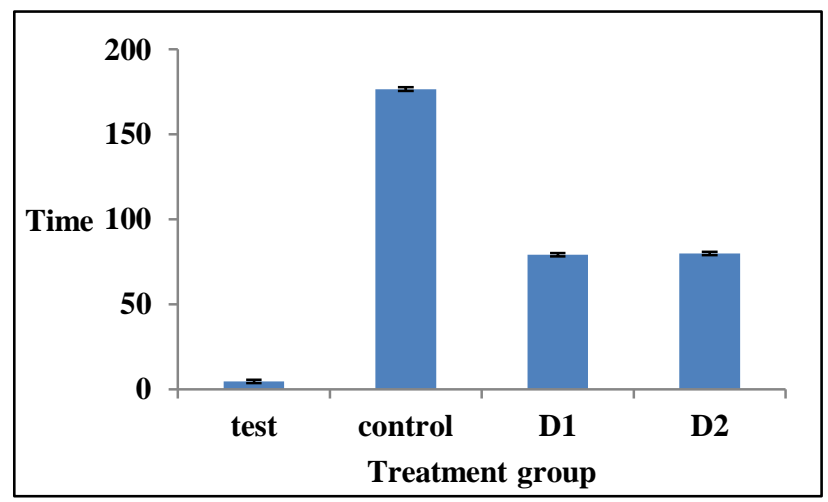

Figure 3: Haloperidol-induced catatonia after 90 minutes.

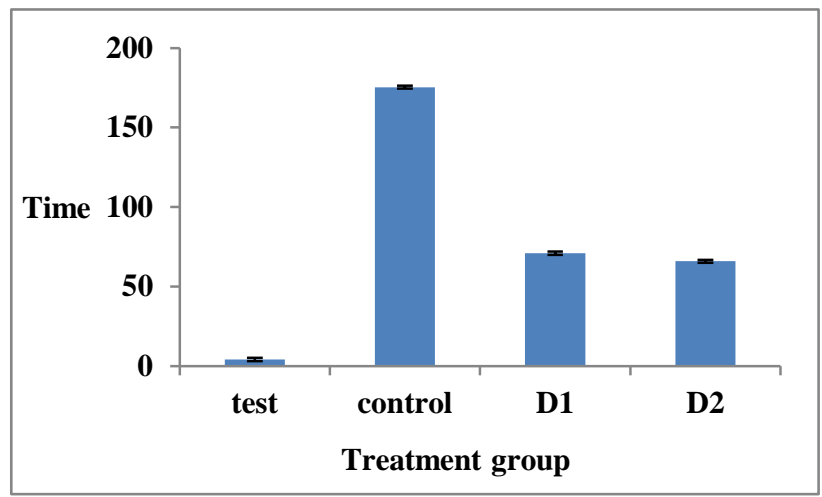

Figure 4: Haloperidol-induced catatonia after 120 minutes.

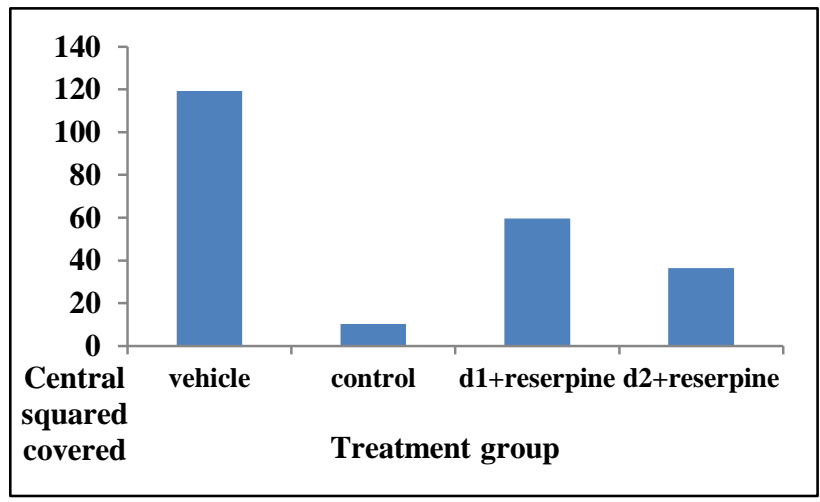

Figure 5: Central square covered.

\section{Lipid peroxidation assay (LPO)}

Level of MDA was increased significantly in reserpine treated group, as compared to that of vehicle treated group, while administration of Ipomoea aquatica MA extract at $400 \mathrm{mg} / \mathrm{kg}$ significantly reduced the levels of MDA as compared with mice treated with reserpine (Table 5, Figure 10). 


\section{The efficacy of SOD and CAT levels in brain}

Levels of the defensive antioxidant enzymes SOD and CAT were decreased after reserpine administration in mice as compared with vehicle treated group. Pretreatment with Ipomoea aquatica MA extract at 400 $\mathrm{mg} / \mathrm{kg}$ resulted in significant elevation of SOD and CAT, as compared with mice treated with reserpine (Table 5, Figure 8,11).

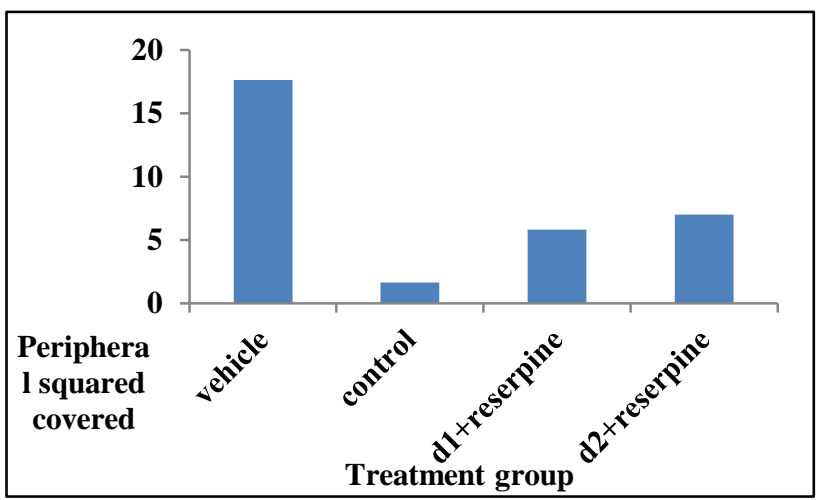

Figure 6: Peripheral square covered.

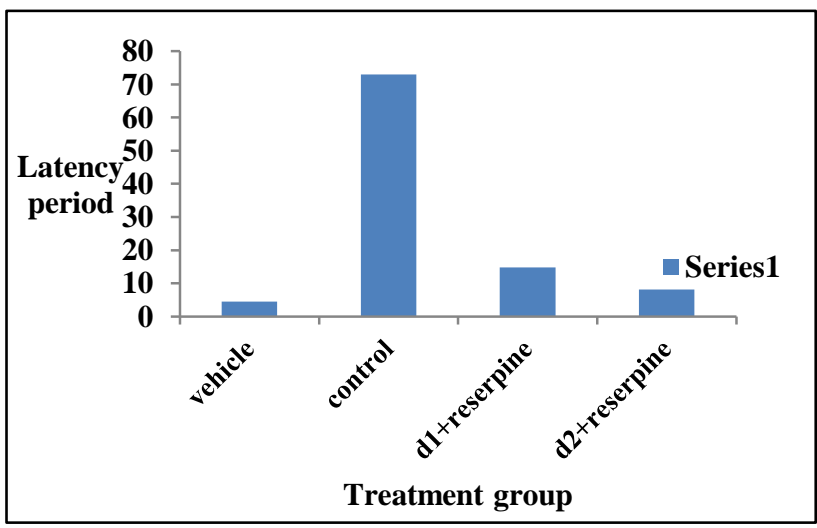

Figure 7: Latency period.

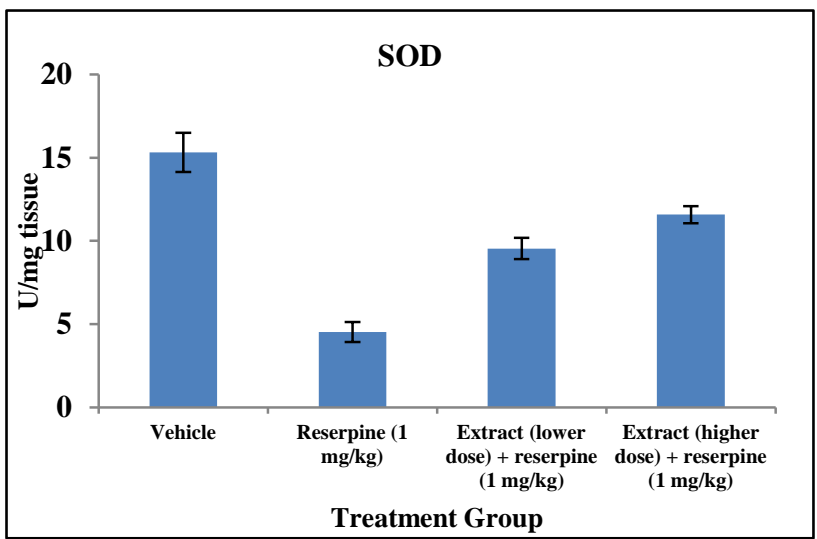

Figure 8: SOD determination.

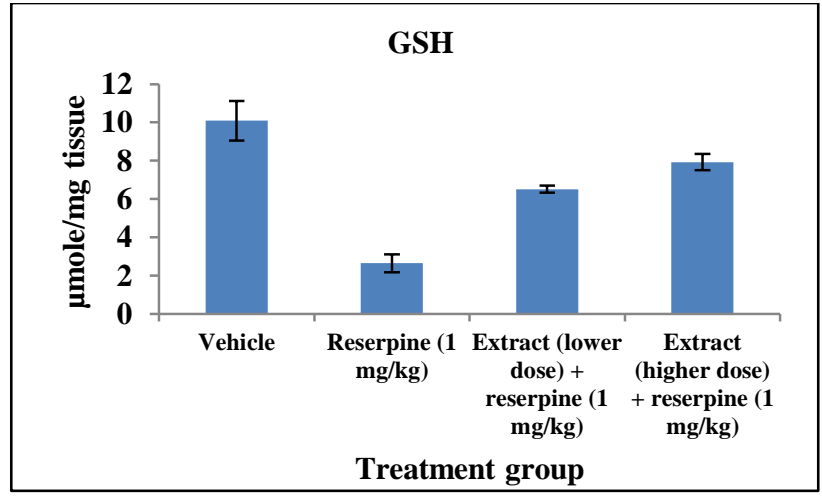

Figure 9: GSH determination.

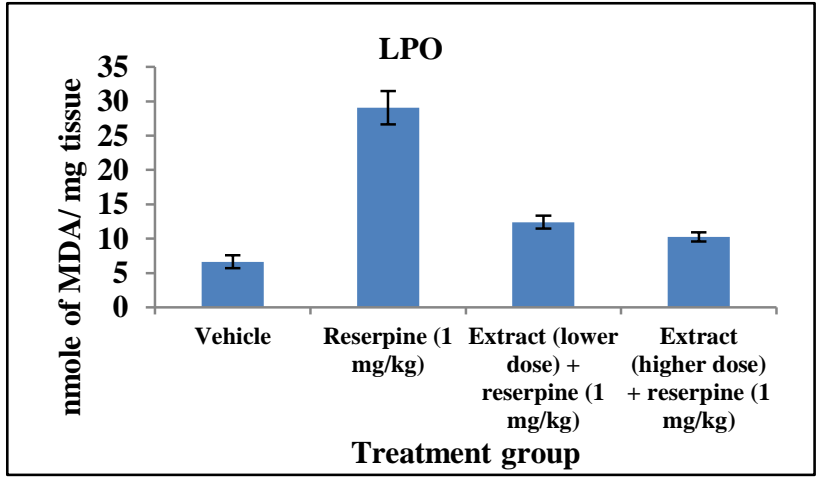

Figure 10: LPO determination.

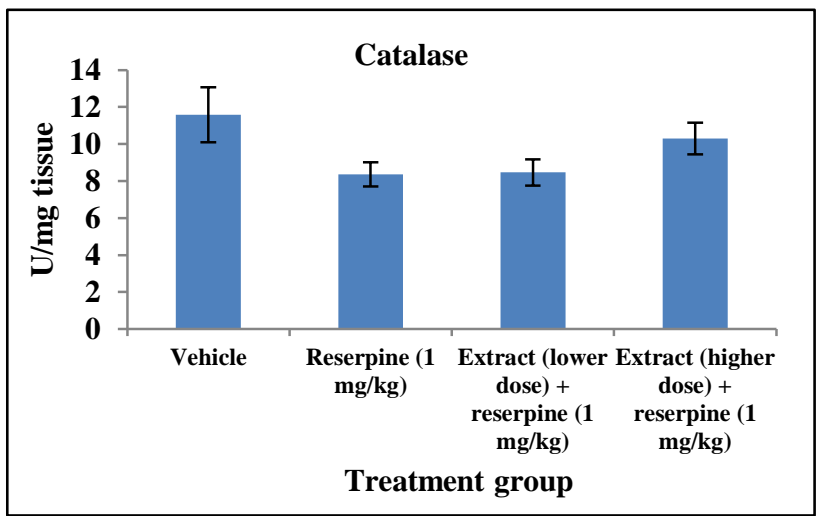

Figure 11: Catalase determination.

\section{Efficacy on brain GSH level}

Content of GSH was depleted significantly in reserpine treated group, as compared with vehicle treated group, indicating about the neurotoxicity induced by the reserpine in mice. On the other hand, GSH levels elevated significantly after Ipomoea aquatica $(400 \mathrm{mg} / \mathrm{kg})$ treatment as compared with reserpine (Table 5, Figure 9).

\section{DISCUSSION}

The present study suggested the protective effect of Ipomoea aquatica on reserpine induced oxidative stress in mice. Neuroleptic-induced catalepsy in rodents has long 
been used as an animal model for screening drugs for Parkinsonism and it is a useful behavioural method for studying nigrostriatal function and its modulation by cholinergic GABAergic serotonergic and nitrergic systems. ${ }^{16}$ In the present investigation it was observed that Ipomoea aquatica MA extract significantly decreased haloperidol induced catatonia at 30, 60, 90 and $120 \mathrm{~min}$ respectively. Extract was found to be more effective at the dose of $400 \mathrm{mg} / \mathrm{kg}$. Thus from the results it can be postulated that selected extract possess effect on dopaminergic receptors in brain.

It has been reported that the administration of Reserpine to mice induces a reduction in the spontaneous locomotor activity, a widely used index of motor impairment in animal studies of parkinson's disease. Reserpine shows their action at the level of intra-neuronal storage vesicles of monoamines (DA, noradrenaline and serotonin) through magnesium- and ATP dependent mechanisms with the resultant depletion of these monoamines in nerve terminals. Thus in present study effect of MA extract of Ipomoea aquatica was investigated in Reserpine induced hypokinesia. Two parameters were considered for assigning effect on locomotion. It was observed that extract at the dose of $400 \mathrm{mg} / \mathrm{kg}$ significantly reduced reserpine induced hypokinesia. Movement in animals was found to be higher as compared to vehicle treated group.

Oxidative stress can be defined as a shift towards oxidation in oxidation reduction reaction, which leads to cellular damage and is stipulated by oxidized products of proteins and lipids. ${ }^{17}$ This effect can be related to the depletion in specific antioxidant mechanisms, such as decreased GSH levels and low level of antioxidant defence system such as catalase and SOD. ${ }^{18}$ Neuroleptics act by blocking dopamine receptor and increase in the turnover of catecholamine which in turn leads to the development of excessive free radical generation. Increased metabolism of catecholamine's produce excessive amount of free radicals which are cytotoxic. ${ }^{19}$ Haloperidol reduces the genetic expression of MnSOD, CuZnSOD and CAT and thus decreases the enzymatic activity of SOD, GSH, and CAT. Chronic haloperidol treatment increases peroxidation of lipid and also nucleic acid peroxidation. ${ }^{20}$ SOD dismutase superoxide radicals to form hydrogen peroxide, which is decomposed to water and oxygen by glutathione peroxidase and catalase, which in turn inhibit the formation of hydroxyl radicals. Our findings of decreased enzymatic and non-enzymatic antioxidants and increased peroxidation of lipid in haloperidol treated group support the involvement of oxidative stress in TD. Ipomoea aquatica alcoholic extract dose dependently decreased the elevated lipid peroxidation levels and increased the levels of SOD and CAT.

Glutathione primarily mediated by reducing inactive disulfide linkages of enzymes to active sulfhydryl group, while on the other hand the sulfhydryl group of glutathione becomes oxidized. Hence glutathione plays an important role in protecting membrane peroxidation and also reduces the levels of hydrogen peroxide by the action of glutathione peroxidase. ${ }^{21}$

Alcoholic extract of Ipomoea aquatica has shown to possess anti-lipid peroxidation effect which is due to removal of hydroxyl and superoxide radicals. Hence the decreased level in lipid peroxidation in the treated group may be due to the elevated levels of antioxidant enzymes SOD and CAT. The estimated glutamate levels in our study revealed a dose dependent reduction in glutamate level in Ipomoea aquatica treated animals. Increased density of dopamine receptors and decreased levels of dopamine is observed in chronic haloperidol treatment. The decreased levels of dopamine may accord to the production of excess free radicals. Ipomoea aquatica has shown an increase in dopamine levels which may reduce the development of super sensitivity due to increased levels of dopamine receptors.

\section{CONCLUSION}

The observed beneficial effects of Ipomoea aquatica in reserpine induced changes in biochemical parameters may be attributed to its diversified chemical components i.e. carbohydrate, starch, protein, glycosides, flavonoids, alkaloids, tannic acid and phenolic compounds. Further investigations of the mechanisms of action of the plant extract, and the active substances responsible for its biological actions, are necessary.

\section{ACKNOWLEDGEMENTS}

The author would like to express his sincere gratefulness and humble regards to his Guide Dr. H.S. Chandel, Principal, Truba Institute of Pharmacy, Bhopal for his cooperative guidance, supervision, critical views and stimulating constructive suggestions, and useful insights throughout the work.

\section{Funding: No funding sources Conflict of interest: None declared \\ Ethical approval: The ethical approval have already been taken by the Institutional animal Ethics Committee of Pinnacle Biomedical Research Institute having Regd. No- 1283/C/09/CPCSEA}

\section{REFERENCES}

1. Gupta YK, Gupta M, Kohli K. Neuroprotective role of melatoninin oxidative stress vulnerable brain. Indian J Physiol Pharmacol. 2003;47:373-86.

2. Wolff SP, Garner A, Dean RT. Free radicals lipids and protein degradation. Trends Biol Sci. 1986;11:27-31.

3. Kumar A, Kulkarni SK. Effect of BR-16A (Mentat), a polyherbal formulation on drug induced catalepsy in mice. Indian J Exper Biol. 2006;44:45-8.

4. Farde L, Nordstrom AL, Wiesel FA, Pauli S, Halldin C, Sedvall G. Positron emission tomographic analysis 
of central D1 and D2 dopamine receptor occupancy in patients treated with classical neuroleptics and clozapine: relation to extra-pyramidal side effects. Arch Gen Psychiatry. 1992;49:538-44.

5. Sanberg PR. Haloperidol-induced catalepsy is mediated by postsynaptic dopamine receptors. Nature 1980;284:472-3.

6. Sagara Y. Induction of reactive oxygen species in neurons by haloperidol. J Neurochem. 1998;71:100212.

7. Arjuman A, Nair V, Gopalkrishna HN, Nandini M. Evaluation of the antioxidant potential of NR-ANXC (a polyherbalformulation) and its individual constituents in reversing haloperidol induced catalepsy in mice. Indian J Pharmacol. 2007;39:1514.

8. Sajak AAB, Abas F, Ismail A, Alfi K. Effect of different drying treatments and solvent ratios on phytochemical constituents of Ipomoea aquatic and co-relation with $\alpha$-glucosidase inhibitory activity. International J Food Properties. 2016;19(8):1859-64.

9. Sivaraman D, Panneerselvam P, Muralidharan P. Invitro screening for acetylcholinesterase enzyme inhibition potential and antioxidant activity of extracts of ipomoea aquatica forsk: therapeutic lead for alzheimer's disease. J Appl Pharmac Scien. 2015;5:12-6.

10. Mital N, Manvar D, Desai T. Exploration of possible mechanisms for anti-inflammatory activity of Ipomoea aquatica. International $\mathbf{J}$ Phytophar. 2015;5:110-8.

11. Khandelwal KR. Practical pharmacognosy. Nirali Prakashan, Pragati Books Pvt. Ltd; 2008;107-13.

12. Agrawal D, Chaudagar K, Appanna V, Mehta A. An antihistaminic activity of vitamin $\mathrm{d}$ in experimental models. World J Pharm Pharmace Scien. 2016;5:1489-97.
13. Sudhakar P, Nair V, Dorababu P, Gopalakrishna HN. Effect of ethanolic extract of leaves of ocimum sanctum on haloperidol induced catalepsy in albino mice. Indian J Pharmacol. 2007;39:87-9.

14. Eftimov M, Dobreva C, Velkova D, Kuzmanova S. Effect of Aronia melanocarpa fruit juice on reserpineinduced hypokinesia and oxydative stress in rats. Scripta Scien Pharma. 2014;1:19-34.

15. Sivaraman D, Muralidaran P. Nootropic effect of Ipomoea aquatica forsk in rat hippocampus. International J PharmTech Res. 2010;2:475-9.

16. Somani RS, Kasture VS, Kasture SB. Haloperidol inhibits (-) bicuculline-induced seizures and bicuculline potentiates haloperidol-induced catalepsy in mice. Indian J Pharmacol. 1999;31:434-6.

17. Shivakumar BR, RavindranathV. Oxidative stress and thiol modification induced by chronic administration of haloperidol. J Pharmacol Exp Ther. 1993;265:1137-41.

18. Elkashef AM, Wyatt RJ. Tardive dyskinesia: possible involvement of free radical and treatment with vitamin E. Schizophr Bull. 1999;25:731-40.

19. Ravindranath V, Reed DJ. Glutathione depletion and formation of glutathione protein mixed disulfide following expose of brain mitochondria to oxidative stress. Bioche Biophys Re Commun. 1990;169:1508.

20. Esterbauer H, Schaur RJ, Zollner H. Chemistry and biochemistry of 4-hydroxy alkenal, malondialdehyde and related aldehydes. Free Radic Biol Med. 1991;11:81-128.

21. Banaclocha MN. Acetylcysteine elicited increase in complex I activity in synaptic mitochondria from aged mice: implications for treatment of Parkinson's disease. Brain Res. 2000;850:173-1.

Cite this article as: Dwivedi G, Tomar V. Protective effect of Ipomoea aquatica against reserpine induced oxidative stress in brain using mice. Int J Basic Clin Pharmacol 2016;5:2123-9. 